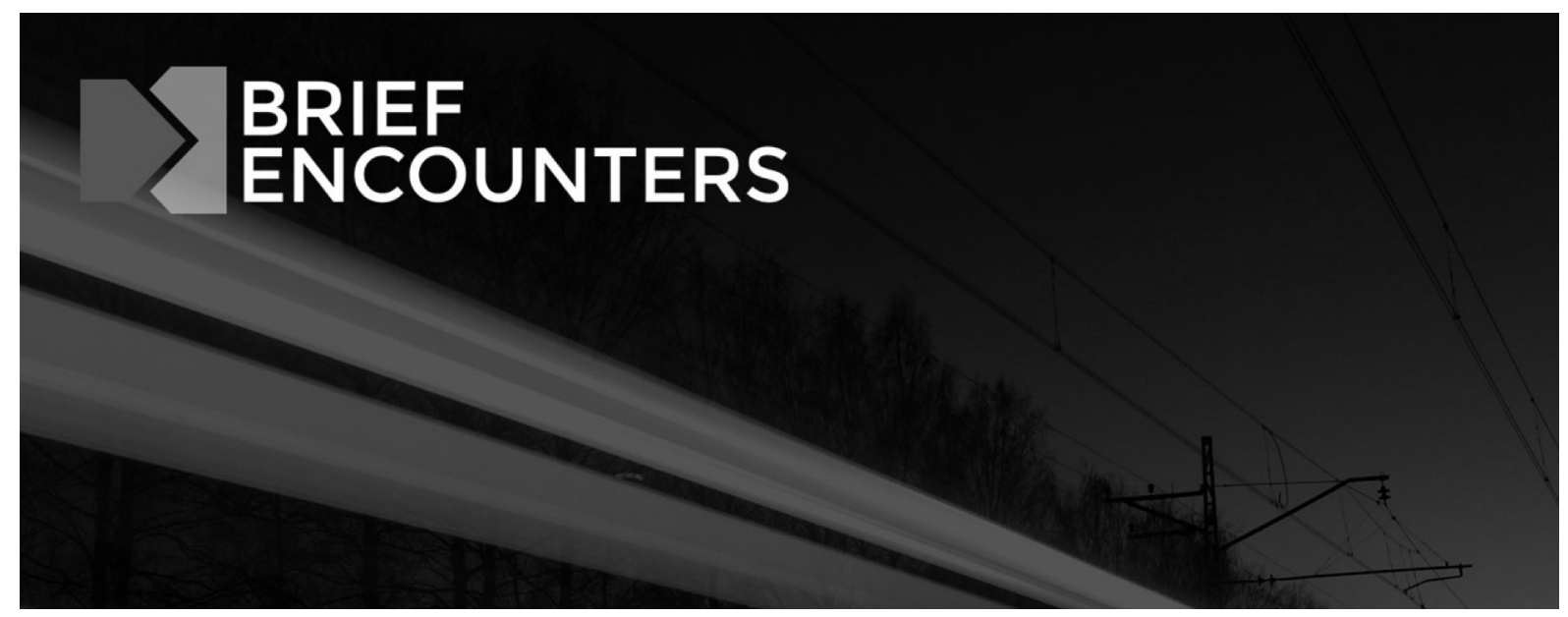

ISSN 2514-0612

Journal homepage: http://briefencounters-journal.co.uk/BE

Review of The Adventures of Gillion de Trazegnies: Chivalry and Romance in the Medieval East

Author(s): Maggie Crosland

Email: maggie.crosland@courtauld.ac.uk

Source: Brief Encounters Vol.1, No. 1 (Feb 2017)

URL: http://briefencounters-journal.co.uk/BE/article/view/35/

DOI: http://dx.doi.org/10.24134/be.v1i1.35

(C) Maggie Crosland, 2017

License (open-access): This is an open-access article distributed under the terms of the Creative Commons Attribution License 4.0, which permits unrestricted use, distribution, and reproduction in any medium, provided the original work is properly cited. No warranty, express or implied, is given. Nor is any representation made that the contents will be complete or accurate or up to date. The publisher shall not be liable for any actions, claims, proceedings, demand or costs or damages whatsoever or howsoever caused arising directly or indirectly in connection with or arising out of the use of this material. 


\section{Review of The Adventures of Gillion de Trazegnies: Chivalry and Romance in the Medieval East}

Maggie Crosland

Elizabeth Morrison and Zrinka Stahuljak, The Adventures of Gillion de Trazegnies: Chivalry and Romance in the Medieval East (Los Angeles: The J. Paul Getty Museum, 2015), 176 pp., \$49.00, ISBN: 9781606064634.

In their volume The Adventures of Gillion de Trazegnies: Chivalry and Romance in the Medieval East, Elizabeth Morrison and Zrinka Stahuljak present an impressive example of the illuminated manuscript monograph. The manuscript in question, the elaborately decorated fifteenth-century Romance of Gillion de Trazegnies, is well known to scholars, but Morrison and Stahuljak's volume is the first to provide a comprehensive study of it. ${ }^{1}$ The book examines the manuscript particularly through the framework of the authors' combined expertise: Morrison is a specialist of Flemish manuscript illumination, Stahuljak of medieval French romance literature. In focusing equally on the textual and visual programmes of the manuscript, the authors weave together a complicated narrative that explores topics such as the northern European view of the East, courtly literary traditions, and artistic patronage.

In the introduction, Morrison and Stahuljak stress the primacy of the object to their study, and this dictates much of the volume's structure, which starts with a discussion of the manuscript's textual and visual elements, and is followed by scholarly interpretation provided by each author in individual essays. The first part of the volume acts as an introduction to the manuscript itself. Commissioned by the Flemish-Burgundian noble Louis of Gruuthuse in c. 1464 and illuminated by the renowned painter Lieven van Latham, the Romance of Gillion de Trazegnies relates the adventures of Gillion, a knight from the county of Hainaut. At the onset

\footnotetext{
${ }^{1}$ Los Angeles, CA, Getty Museum, MS Romance of Gillion de Trazegnies Ms. III.
} 
of the volume, Stahuljak provides a plot summary to the tale - detailing the complicated story of Gillion's pilgrimage to Jerusalem, his double marriage to Marie d'Ostrevant and the Egyptian princess Gracienne, his reunion with his sons, and his return to Hainaut. Also included is an impressive presentation of the manuscript's visual programme, with each of the remaining eight half-page miniatures and forty-four historiated initials reproduced in sequence with either related transcriptions or descriptive summaries. The result of this pseudo-facsimile is striking. While it does not recreate the book word-for-word nor in scale, it enables the reader to understand how the illuminations and the words correspond to forward the story's narrative.

In their interpretive essays, Stahuljak and Morrison consider how the patronage of Louis of Gruuthuse, as well as contemporary Flemish-Burgundian culture, is reflected in the manuscript's textual and visual programmes. In her essay Stahuljak considers the literary context of the manuscript. She effectively explains the broad factors that led to the manuscript's creation, from the development of the story in the fifteenth century to how the Getty codex may reflect the specific interests of Gruuthuse as a noble in the court of Philip the Good, Duke of Burgundy. Discussed, for instance, is the possible oral transmission of tales such as that of Gillion within the particular political climate of Burgundy in the decade after the fall of Constantinople to the Ottoman Empire, when Philip was eager to mount a crusade of his own. It is in this context that Louis of Gruuthuse and Philip's bastard son Anthony of Burgundy, both high ranking nobles at the Burgundian court, commissioned the only two known long-text versions of the Romance of Gillion de Trazegnies. Stahuljak also considers Gruuthuse's own political career to explain key textual differences between his codex and Anthony's, with particular attention to how the commission of Gruuthuse's manuscript corresponds with his appointment to the Burgundian Order of the Golden Fleece in 1461 and as Governor General of Holland, Zeeland, and Frisia in 1463. ${ }^{2}$ She argues that these personal

\footnotetext{
${ }^{2}$ Dülmen, private collection, MS Romance of Gillion de Trazegnies.
} 
successes may explain why Gruuthuse's text focuses more on the character of Gillion than does Anthony's version.

Morrison's essay turns to a discussion of the cycle of the miniatures within the manuscript and the artist Lieven van Lathem. The author provides a codicological study of the manuscript, focusing on how its plan changed during its creation, and on what content is now missing from its leaves. Morrison also conducts a close comparison of the Getty and Dülmen manuscripts to highlight changes in content and to explore how imagery and narrative have been translated differently from one to the other. For example, while the illuminations of the Getty Gillion are given to van Latham and those of the Dülmen version to his workshop, the latter predates the former and there is enough consistency between the two to suggest that the Dülmen manuscript served as a model of sorts for Gruuthuse's. The place of the manuscript within Gruuthuse's immense library is also considered. This discussion complements Stahuljak's argument that the commission was a reaction to both Gruuthuse's place within the Burgundian court and the crusade preparations that were taking place there, as while this was the only text of an Eastern subject matter commissioned by him, it was particularly reflective of his needs at that time.

The volume was published following the Getty's acquisition of the manuscript in 2012, and its presentation is unquestionably celebratory. Morrison and Stahuljak at once gear their discussion towards a scholarly audience, unpacking a great deal of complicated historical and codicological information, and also make the content accessible to a general audience. This is seen clearly in an appendix presenting diagrams of the gatherings of the codex, which gives the construction of the Romance of Gillion de Trazegnies in a manner standard to manuscript studies alongside a description of how to read the diagrams meant for non-scholarly readers. While this approach has resulted in a relatively short volume, Morrison and Stahuljak have largely avoided the danger of compromising their research by clearly signposting and 
explaining their more nuanced arguments regarding codicology, political influence, and cultural exchange.

Together Morrison and Stahuljak provide a refreshing take on the manuscript monograph. They celebrate the Romance of Gillion de Trazegnies as an object, reproducing Lieven van Latham's illuminations in stunning detail and presenting the plot of the chivalric romance to effect. Moreover, they place the manuscript within the literary, artistic, and political context in which it was made by using a truly interdisciplinary approach. All too frequently, manuscript studies proclaim the intention of providing text-image analyses, but focus instead on the images with only cursory consideration of how those illuminations reflect the words they accompany. Yet the authors here approach these two elements together in order to study the manuscript not just as an artistic production, but as the result of the political and cultural climate in which it was made. Above all, this volume raises the possibilities of what we may discover about objects such as the Romance of Gillion de Trazegnies by applying cross-disciplinary approaches to their study. 